\title{
Decline in spirometric variables in grain workers from start of employment: differential effect of duration of follow up
}

Jan E Zejda, Punam Pahwa, James A Dosman

\begin{abstract}
Prospective study of 164 young men from the start of employment in grain elevators showed that of those seen at the initial evaluation of respiratory state only $30 \%$ were available for a complete four year follow up. The drop out of subjects could represent a health related selection leading to the underestimation of respiratory effects of exposure to grain dust as assessed in the survivor group. This hypothesis was examined by comparisons of longitudinal changes in lung function in four groups defined by the duration of follow up involving the initial examination and periodic evaluations after one, two, and four years of work. Sixty four men were tested only on the initial examination (group I), 18 underwent two (group II), 31 underwent three (group III), and 51 (group IV) all four examinations. The groups had similar mean ages (range: 19.4-20.1 years), mean duration of previous exposure to grain dust (range: 8-13 weeks), smoking habits, lung function, and prevalences of respiratory symptoms evaluated on the initial occasion. The average decline in lung function over the first year was associated with duration of follow up. The annual decline in FVC (ml) was 58 in group II, 41 in group III and - 55 (increase) in group IV; the decline in FEV $(\mathrm{ml})$ was 224, 130, and 70 respectively. The differences for the annual declines of $\mathrm{FEV}_{1}, \mathrm{FEF}_{25-75}, \dot{\mathrm{V}}_{\max 50}$, and $\operatorname{Vmax}_{25}$ were significant between groups II and IV, and the $F E F_{25-7 s}, \dot{\mathbf{V}}_{\max 50}$, and $\dot{V}_{\max 25}$ differed significantly between groups II and III. The results show that the restriction of analysis to the survivors may underestimate the relation between work and respiratory impairment.
\end{abstract}

Centre for Agricultural Medicine, University of Saskatchewan, Saskatoon, Canada

J E Zejda, P Pahwa, J A Dosman

Dr Zejda is on leave from the Institute of Occupational Medicine, Sosnowiec, Poland
Cross sectional studies conducted in the grain industry show a relatively low prevalence of asthma, ${ }^{12}$ low prevalence of atopy, ${ }^{3-6}$ and relatively well preserved mean values of standard indices of lung function. ${ }^{3578}$ These findings are thought to result from health selection of workers affected by respiratory disorders. ${ }^{9-11}$ Such an effect was suggested by a longitudinal study that showed a significantly higher prevalence of respiratory symptoms but not functional respiratory impairment in the subjects who left the grain industry than in those who continued work. $^{8}$

The occurrence of acute spirometric changes shortly after starting employment in the grain industry is well known. ${ }^{12-15}$ In workers who continue employment and remain under study these changes appear to follow an early recovery pattern. ${ }^{15}$ It is not known whether the workers who leave the grain industry in their first years of employment experience similar spirometric changes, and whether these changes differ between "survivors" who stay in the industry and "drop-outs" who leave the industry. The concept of health selection implies that the degree of functional response to the occupational environment could be associated with future job state in the grain industry.

The present paper describes the results of longitudinal study of lung function in young men who had just begun employment in grain elevators. We examined annual spirometric changes in groups of workers who differ in duration of follow up.

\section{Methods}

The subjects were men commencing employment with the Saskatchewan Wheat Pool in 1980. The evaluation of respiratory state included a detailed interview and tests of lung function performed at the Division of Respiratory Medicine, Department of Medicine, University Hospital in Saskatoon, Saskatchewan.

All subjects completed a questionnaire on respiratory symptoms based on the American Thoracic 
Table 1 Mean age, duration of exposure, height, weight, and lung function according to duration of follow up. Measurements obtained at the initial examination

\begin{tabular}{|c|c|c|c|c|c|c|c|c|c|c|c|}
\hline Group & $\begin{array}{l}\text { No of } \\
\text { subjects }\end{array}$ & $\operatorname{Age}(y)$ & $\begin{array}{l}\text { Duration } \\
\text { of work } \\
\text { (weeks) }\end{array}$ & $\begin{array}{l}\text { Height } \\
(\mathrm{cm})\end{array}$ & $\begin{array}{l}\text { Weight } \\
\text { (kg) }\end{array}$ & $\begin{array}{l}F V C \\
(\% p v)\end{array}$ & $\begin{array}{l}F E V, \\
(\% p v)\end{array}$ & $\begin{array}{l}F E V, F V C \\
(\% p v)\end{array}$ & $\begin{array}{l}F E F_{2 s-7 s} \\
(\% p v)\end{array}$ & $\begin{array}{l}\dot{V}_{\text {maxso }} \\
(\% p v)\end{array}$ & $\begin{array}{l}\dot{V}_{\max 25} \\
(\% p v)\end{array}$ \\
\hline $\begin{array}{r}\text { I } \\
\text { II } \\
\text { III } \\
\text { IV }\end{array}$ & $\begin{array}{l}64 \\
18 \\
31 \\
51\end{array}$ & $\begin{array}{l}19.4 \\
20 \cdot 1 \\
20 \cdot 1 \\
19.5\end{array}$ & $\begin{array}{r}9 \\
13 \\
11 \\
10\end{array}$ & $\begin{array}{l}175 \\
180 \\
173 \\
175\end{array}$ & $\begin{array}{l}75 \\
76 \\
77 \\
76\end{array}$ & $\begin{array}{l}106 \\
106 \\
103 \\
105\end{array}$ & $\begin{array}{l}103 \\
101 \\
102 \\
104\end{array}$ & $\begin{array}{l}97 \\
95 \\
98 \\
99\end{array}$ & $\begin{array}{r}96 \\
92 \\
98 \\
100\end{array}$ & $\begin{array}{r}97 \\
90 \\
97 \\
102\end{array}$ & $\begin{array}{l}95 \\
87 \\
93 \\
99\end{array}$ \\
\hline Total & 164 & $19 \cdot 6$ & 10 & 176 & 76 & 105 & 103 & 98 & 97 & 98 & 95 \\
\hline
\end{tabular}

Group I-Subjects participating only in the first examination. Group II-Subjects participating only in the first and second examinations. Group IIISubjects participating only in the first, second, and third examinations. Group IV-Subjects participating in all four examinations.

$\% p v=\%$ of predicted values.

Society (ATS) questionnaire ${ }^{16}$ and answered further questions concerning symptoms related directly to exposure to grain. Tests of lung function included the measurement of forced vital capacity (FVC(1)), forced expiratory volume in the first second $\left(\mathrm{FEV}_{1}(1)\right)$, the $\mathrm{FEV}_{1} / \mathrm{FVC}$ ratio (\%), maximum midexpiratory flow rate $\left(\mathrm{FEF}_{25-75}(\mathrm{l} / \mathrm{s})\right)$, and maximum expiratory flow rates at $50 \%$ and $25 \%$ of vital capacity $\left(\dot{\mathrm{V}}_{\max 50}, \dot{\mathrm{V}}_{\max 25}(\mathrm{l} / \mathrm{s})\right)$. The measurements were obtained using a computerised pneumotachograph (Fleisch No 4) and a technique that conformed to the 1979 ATS recommendations. ${ }^{17}$ Predicted values for FVC, $\mathrm{FEV}_{1}, \mathrm{FEV}_{1} / \mathrm{FVC}$, and $\mathrm{FEF}_{25-75}$ were calculated using the equations of Crapo et al. ${ }^{18}$ For $\dot{\mathrm{V}}_{\max 50}$ and $\dot{\mathrm{V}}_{\max 25}$ the equations of Knudson et al were used. ${ }^{19}$

The surveillance programme was carried out on all new grain workers and involved an initial examination ("zero year") and a periodic evaluation of respiratory symptoms and lung function, performed after one, two, and four years of employment.

Changes in lung function between the initial (test $\left.t_{i}\right)$ and subsequent (test $t_{s}$ ) examinations were calculated as absolute differences (test $t_{i}$-test $t_{3}$ ) and as percentage differences (test $t_{i}$-test $/$ test $_{i}$ ) $\times 100$ ). Statistical analyses were performed using SAS software. ${ }^{20}$ Differences between categorical variables (symptoms) were assessed by means of $\chi^{2}$ analysis and between linear variables (lung function changes) by $t$ test, with a level of significance of $p<0.05$.

\section{Results}

The initial examination (test $t_{i}$ ) was performed on 223 workers whose age ranged from 17 to 41 and previous exposure to grain dust ranged from 0 to 728 weeks. To diminish the potential effect of previous exposure to grain and to reduce the age span the analysis was restricted to 164 men who had worked no longer than 52 weeks in a previous grain related job and who were 25 years old or less at the time of the initial evaluation. Table 1 shows the mean age, duration of occupational exposure to grain dust, and height, weight, and lung function test variables obtained on the initial evaluation.

According to the number of available follow up tests per person the subjects were divided into four groups: group I, 64 men seen only on the first examination; group II, 18 men seen on the first and second examinations; group III, 31 men seen on the first, second, and third examinations; group IV, 51 men seen on all four occasions. These groups did not differ in mean age, duration of exposure to grain, and lung function (table 1). We found no significant between group differences in smoking, occurrence of grain related symptoms, symptoms of chronic bronchitis, or asthma and pneumonia in the past (table 2).

The figure shows mean values for the four tests of lung function (FVC, $\mathrm{FEV}_{1}, \mathrm{FEF}_{25-75}$, and $\dot{\mathrm{V}}_{\max 25}$ ) obtained on initial and subsequent examinations. The longitudinal changes differ between the groups

Table 2 Smoking habit, prevalence of symptoms related to exposure to grain, symptoms of chronic bronchitis, and respiratory diseases diagnosed in the past according to duration of follow up

\begin{tabular}{|c|c|c|c|c|c|c|c|c|c|}
\hline \multirow[b]{2}{*}{ Group } & \multirow[b]{2}{*}{$\begin{array}{l}\text { No of } \\
\text { subjects }\end{array}$} & \multirow[b]{2}{*}{$\begin{array}{l}\text { Smokers } \\
(\%)\end{array}$} & \multicolumn{4}{|c|}{ Grain related irritation of: } & \multirow{2}{*}{$\begin{array}{l}\text { Chronic } \\
\text { bronchitis } \\
(\%)\end{array}$} & \multirow[b]{2}{*}{$\begin{array}{l}\text { Asthma } \\
(\%)\end{array}$} & \multirow[b]{2}{*}{$\begin{array}{l}\text { Pneumonia } \\
(\%)\end{array}$} \\
\hline & & & $\begin{array}{l}\text { Eyes } \\
(\%)\end{array}$ & $\begin{array}{l}\text { Nose } \\
(\%)\end{array}$ & $\begin{array}{l}\text { Throat } \\
(\%)\end{array}$ & $\begin{array}{l}\text { Skin } \\
(\%)\end{array}$ & & & \\
\hline $\begin{array}{l}\text { II } \\
\text { III } \\
\text { IV }\end{array}$ & $\begin{array}{l}64 \\
18 \\
31 \\
51\end{array}$ & $\begin{array}{l}53 \\
28 \\
45 \\
44\end{array}$ & $\begin{array}{l}37 \\
22 \\
26 \\
39\end{array}$ & $\begin{array}{l}39 \\
33 \\
39 \\
41\end{array}$ & $\begin{array}{r}11 \\
0 \\
3 \\
7\end{array}$ & $\begin{array}{l}39 \\
39 \\
38 \\
43\end{array}$ & $\begin{array}{r}13 \\
5 \\
7 \\
6\end{array}$ & $\begin{array}{l}6 \\
0 \\
0 \\
0\end{array}$ & $\begin{array}{l}14 \\
17 \\
10 \\
17\end{array}$ \\
\hline Total & 164 & 46 & 34 & 39 & 7 & 40 & 9 & 2 & 14 \\
\hline
\end{tabular}

Asthma and pneumonia in the past recorded by subjects themselves. 

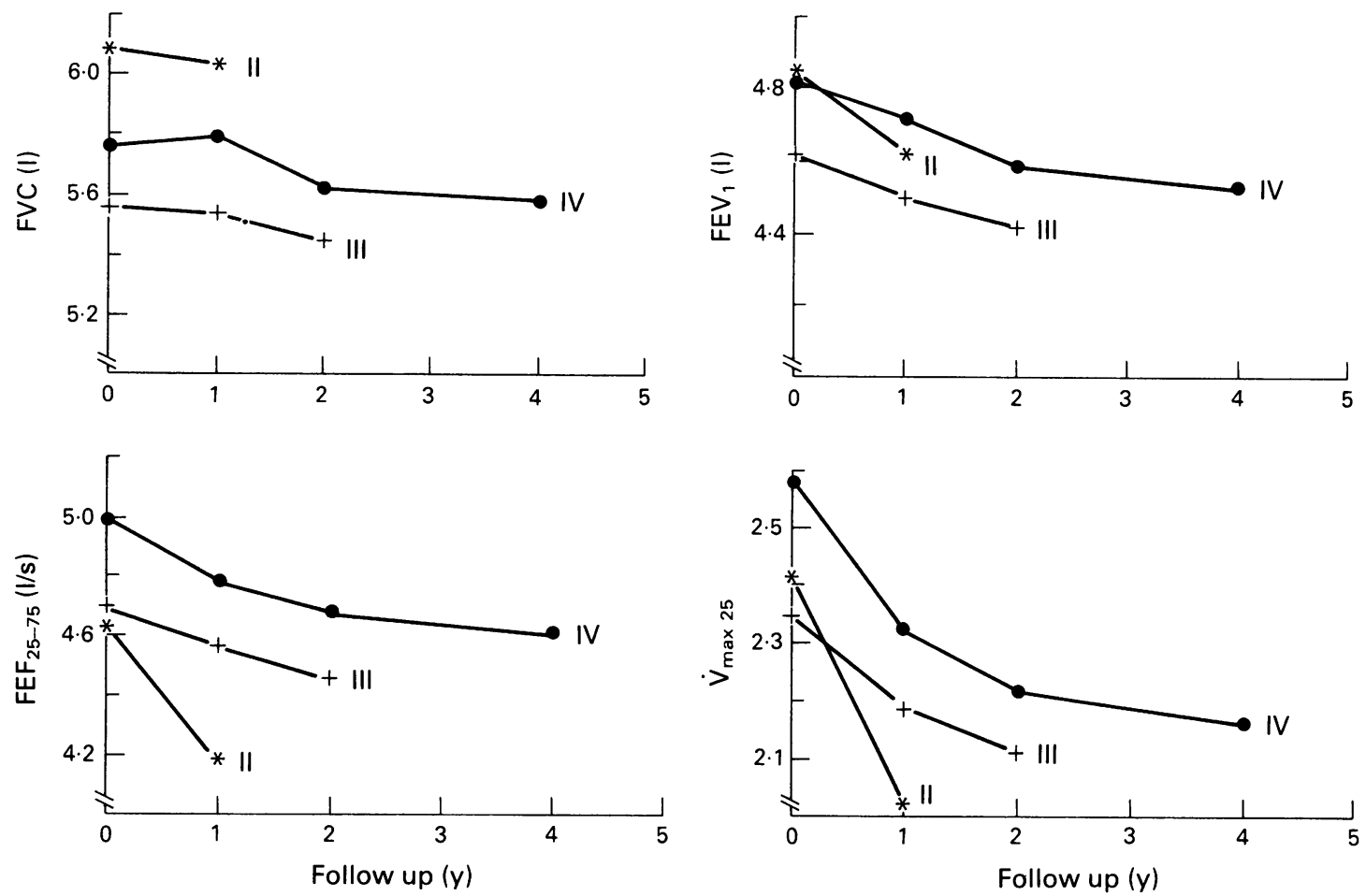

Mean values of lung function tests $\left(F V C, F E V_{1}, F E F_{25-75}\right.$, and $\left.\dot{V}_{\max 25}\right)$ in three groups of grain workers, defined according to duration of follow up. II-subjects participating only in first and second examinations; III-subjects participating only in first, second, and third examinations; IV-subjects participating in all four examinations.

(table 3). The largest decline over the first year occurred in 18 subjects with the shortest follow up. When compared with group IV ("survivors") the group with only two examinations was characterised by significantly larger declines $(p<0.05)$ in $\mathrm{FEV}_{1}$, $\mathrm{FEF}_{25-75}, \dot{\mathrm{V}}_{\max 50}$, and $\dot{\mathrm{V}}_{\max 25}$. The group with three tests occupied an intermediate position for annual changes in lung function, with significantly larger declines in $\mathrm{FEF}_{25-75}$ and $\dot{\mathrm{V}}_{\max 25}$ than in those who were "survivors". These differences were also significant for percentage declines (not shown).

The degree of annual decline was not related to smoking habit and did not correlate with age, height, or duration of exposure to grain dust calculated on initial examination. In group III, the declines in FVC and $\mathrm{FEV}_{1}$ were associated with weight $(r=-0.49(p=0.005)$ and $r=-0.39(p=0.033)$ respectively). In group IV the absolute declines of $\mathrm{FEV}_{1} / \mathrm{FVC}, \mathrm{FEF}_{25-75}$, and $\dot{\mathrm{V}}_{\max 25}$ depended on the initial values of these indices $(r=0.41(p=0.003)$, $r=0.33(p=0.017), r=0.52(p=0.001)$ respectively). Both groups with at least three consecutive examinations (group III and IV) were similar in terms of decline in lung function over two years.

Table 3 Decline in lung function over the first year of observation according to duration of follow up

\begin{tabular}{|c|c|c|c|c|c|c|c|c|}
\hline \multirow[b]{2}{*}{ Group } & \multicolumn{8}{|c|}{ Absolute difference between initial and second examination } \\
\hline & $\begin{array}{l}\text { No of } \\
\text { subjects }\end{array}$ & $\begin{array}{l}F V C \\
(m l)\end{array}$ & & $\begin{array}{l}F E V, \\
(m l)\end{array}$ & $\underset{(\%)}{F E V}{ }_{1} / F V C$ & $\begin{array}{l}F E F_{25-75} \\
(l / s)\end{array}$ & $\begin{array}{l}\dot{V}_{\operatorname{maxso}} \\
(l / s, !\end{array}$ & $\begin{array}{l}\dot{V}_{\max 25} \\
(l / s)\end{array}$ \\
\hline $\begin{array}{l}\text { II } \\
\text { III } \\
\text { IV }\end{array}$ & $\begin{array}{l}18 \\
31 \\
51\end{array}$ & $\begin{array}{r}58 \\
41 \\
-55\end{array}$ & $\begin{array}{l}(42) \\
(39) \\
(38)\end{array}$ & $\begin{array}{cc}224^{\star} & (218) \\
130 & (286) \\
70 & (267)\end{array}$ & $\begin{array}{ll}2.8 & (3.4) \\
1.7 & (3.2) \\
1.9 & (2.9)\end{array}$ & $\begin{array}{l}0.45^{\star}(0.40) \\
0.14{ }^{\dagger}(0.65) \\
0.14 \quad(0.60)\end{array}$ & $\begin{array}{ll}0.34^{\star} & (0.60) \\
0.14 & (0.66) \\
0.01 & (0.77)\end{array}$ & $\begin{array}{l}0.39^{\star}(0.28) \\
0 \cdot 15 \dagger(0.46) \\
0.20(0.41)\end{array}$ \\
\hline
\end{tabular}

Values are means (SD).

$\star$ Difference statistically significant between group II and group IV.

$\dagger$ Difference statistically significant between group II and group III. 


\section{Discussion}

The findings show that a longitudinal study of a group of workers commencing employment in the grain industry was vulnerable to a substantial drop out of subjects from follow up. Almost $\mathbf{4 0 \%}$ of subjects participated only in the first examination and $30 \%$ were available for the complete four year follow up. The specific reasons for the different numbers of examinations completed by subjects are unknown. Under the terms of the surveillance programme all new employees were required to attend the scheduled periodic examinations. The possibility that the subjects who participated only in the initial evaluation were seasonal workers, and thus were not referred for subsequent testing cannot be excluded. The use of seasonal workers by the companies in this location, however, is rare. Similarly, the reasons why some subjects were available for two and some for three periodic examinations are not known.

The drop out of subjects could represent a rapid job turnover among grain workers in their initial years of employment. In other dusty occupations the rate at which workers terminate their employment was found to be related to reasons of health..$^{21-23}$ Studies on drop outs in the grain industry are scarce, despite indirect evidence provided by cross sectional studies for health selection as a factor in drop out. One study that has considered this issue directly showed that subjects who had left their jobs during the interval between the first and the second surveys had significantly more symptoms of cough and shortness of breath than those who were available for testing on both occasions. ${ }^{8}$ Both groups had similar lung function at the first examination and the "survivors" were found to have a slow decline in lung function over the study period. Spirometric changes in "drop out" subjects were unknown in that study. In our population of workers, the prevalence of atopy as measured by allergic skin tests in those commencing employment was lower than in control subjects on the first evaluation, and this difference had increased after one year. ${ }^{6}$ Cases of health selection occurring early in employment have been reported by another study in which young atopic subjects with a history of wheezing were found to leave the industry due to the development of asthmatic symptoms. ${ }^{15}$

The present report does not provide sufficient data to discuss job turnover and to link its degree with health disorders triggered by exposure to dust, because the specific reasons for differing follow ups are unknown. This report considers another issue, however, that is of central importance for occupational epidemiology. Our study suggests that restriction of follow up to "survivors" may underestimate the extent of work related respiratory disorders. In our study, subjects who did not attend for a full follow up (and probably left the industry) had significantly larger annual declines in lung function than those who attended for a full follow up. This effect depended on the duration of longitudinal study. In comparison with "survivors", the largest annual decline in lung function was seen in the subjects with the shortest follow up. These differing degrees of respiratory responses to grain dust were not explained by age, duration of exposure, smoking habit, or initial lung function. Furthermore, the identified groups were similar in terms of grain related symptoms and past respiratory illnesses. It is possible that "host related" factors resulted in differing degrees of flow obstruction in response to the respiratory challenge posed by the occupational environment. This issue, however, is beyond the scope of our study.

In conclusion, our results showed that restriction of follow up to "survivors" is associated with a bias of underestimation of work related respiratory impairment in populations occupationally exposed to dust.

Requests for reprints to: Dr J E Zejda, Centre for Agricultural Medicine, Royal University Hospital, Wing 3E, Saskatoon S7N 0X0, Saskatchewan, Canada.

1 Dosman JA, Cotton DJ, Graham BL, Li KYR, Froh F, Barnett GD. Chronic bronchitis and decreased forced expiratory flow rates in lifetime non-ssmoking grain workers. Am Rev Respir Dis 1980;121:11-6.

2 Chan-Yeung M. Grain dust asthma, does it exist? In: Dosman JA, Cockcroft JA, eds. Principles of health and safety in agriculture. Boca Raton, Florida: CRC Press Inc, 1989: $169-71$.

3 Chan-Yeung $M$, Schulzer $M$, MacLean $L$, Dorken E, Grzybowski S. Epidemiologic health survey of grain elevator workers in British Columbia. Am Rev Respir Dis 1980;121: 329-38.

4 doPico G, Reddan W, Anderson S, Flaherty D, Smalley E. Acute effects of grain dust exposure during a work shift. Am Rev Respir Dis 1983;128:399-404.

5 Yach D, Myers J, Bradshaw D, Benatar SR. A respiratory epidemiologic survey of grain mill workers in Cape Town, South Africa. Am Rev Respir Dis 1985;131:505-10.

6 Dosman JA, McDuffie HH, Pahwa P. Atopic status as a factor in job decision making in grain workers. J Occup Med 1991; 33:1007-10.

7 Cotton DJ, Graham BL, Li KYR, Froh F, Barnett GD, Dosman JA. Effects of grain dust exposure and smoking on respiratory symptoms and lung function. J Occup Med 1983;25:131-41.

8 Broder I, Corey P, Davies G, et al. Longitudinal study of grain elevator and control workers with demonstration of healthy worker effect. J Occup Med 1985;27:873-80.

9 Chan-Yeung $M$, Enarson D, Grzybowski S. Grain dust and respiratory health. Can Med Assoc J 1985;15:969-73.

10 Broder I. Overview of adverse pulmonary effects of grain dust. In: Dosman JA, Cockcroft JA, eds. Principles of health and safety in agriculture. Boca Raton, Florida: CRC Press Inc, 1989:97-103.

11 Blainey AD. Respiratory disease in grain workers. Respir Med 1990;84:93-5.

12 Broder I, Hutcheon MA, Mintz S, et al. Changes in respiratory variables of grain handlers and civic workers during their initial months of employment. Br J Ind Med 1984;41:94-9.

13 James AL, Coockson WOCM, Buters G, et al. Symptoms and longitudinal changes in lung function in young seasonal grain handlers. Br J Ind Med 1986;43:587-91.

14 Broder I, Mintz S, Hutcheon MA, Corey PN, Kuzyk J. Effect of 
layoff and rehire on respiratory variables of grain elevator workers. Am Rev Respir Dis 1980;122:601-8.

15 James AL, Zimmerman MJ, Ee H, Ryan G, Musk AW. Exposure to grain dust and changes in lung function. $\mathrm{Br} J$ Ind Med 1990;47:466-72.

16 Ferris BG. Epidemiology standardization project. II. Recommended respiratory disease questionnaires for use with adults and children in epidemiological research. Am Rev Respir Dis 1978;118:7-53.

17 American Thoracic Society. Snowbird workshop on standardization of spirometry. Am Rev Respir Dis 1979;119:881-8.

18 Crapo RO, Morris AH, Gardner RM. Reference spirometric values using techniques and equipment that meet ATS recommendations. Am Rev Respir Dis 1981;123:659-64.

19 Knudson RJ, Slatin RC, Lebowitz MD, Burrows B. The maximal expiratory flow-volume curve. Am Rev Respir Dis 1976;113:587-600.

20 SAS Institute Inc. SAS/STAT Users guide. Release 6.03. Edition. Cary NC: SAS Institute Inc, 1985:549-640.

21 Koskela R-S, Luoma K, Hernberg S. Turnover and health selection among foundry workers. Scand $J$ Work Environ Health 1976;2(suppl 1):90-105.

22 Koskela R-S, Jarvinen E, Korhonen H, Mutanen P. Health selection among metal workers. Scand J Work Environ Health 1983;9:155-61.

23 Chan-Yeung M, Enarson DA, MacLean L. Longitudinal study of workers in an aluminium smelter. Arch Environ Health 1989;44:134-9.

Accepted 11 November 1991

\section{Correspondence and editorials}

The British Journal of Industrial Medicine welcomes correspondence relating to any of the material appearing in the journal. Results from preliminary or small scale studies may also be published in the correspondence column if this seems appropriate. Letters should be not more than $\mathbf{5 0 0}$ words in length and contain a minimum of references. Table and figures should be kept to an absolute minimum. Letters are accepted on the understanding that they may be subject to editorial revision and shortening.

The journal now also publishes editorials which are normally specially commissioned. The Editor welcomes suggestions regarding suitable topics; those wishing to submit an editorial, however, should do so only after discussion with the Editor. 